\title{
Kejahatan Main Hakim Sendiri (Eigenrichting) Menurut Hukum Positif Dan Fiqh jinayah
}

\author{
Sumardi Efendi \\ STAI Al-Washliyah Banda Aceh \\ sumardi.efendi5@gmail.com
}

\begin{abstract}
Eigenrichting itself is a crime that can cause harm to the offender as a result of his own actions, this action arises due to mistrust and distrust of law enforcement and the law itself is confronted by the public. On the other hand, as a result of these actions resulted in the emergence of victims, herein lies the problem to be investigated in this study of how eigenrichting acts which initially as a form of public response from crime turn themselves into criminals. This type of research is the Library Research, with the nature of analytic-comparative research with a juridical-normative approach. From the results of the study it was concluded that in positive law perpetrators of eigenrichting crimes can be charged under article 170 of the Criminal Code, regulating legal sanctions for perpetrators of violence against people or goods in public while in fiqh the jinayah is known as al-tawfuq where several people who commit a crime together without prior agreement because of the psychological influence and thoughts that come suddenly and the given uqubat will also be dropped according to their respective roles.
\end{abstract}

Keywords: crime, eigenrichting, positive law, jinayah fiqh

\begin{abstract}
Abstrak
Main hakim sendiri merupakan suatu kejahatan yang bisa menimbulkan kerugian bagi pelaku akibat dari tindakannya sendiri, tindakan ini muncul akibat mistrust and distrust terhadap penegak hukum dan hukum itu sendiri dihadapkan masyarakat. Dilain pihak akibat tindakan tersebut mengakibatkan timbulnya korban, disinilah letak permasaalahan yang akan ditiliti dalam penelitian ini bagaimana tindakan main hakim sendiri yang pada mulanya sebagai bentuk respons masyarakat dari kejahatan berubah mereka sendiri menjadi pelaku kejahatan. Jenis penelitian ini adalah Library Research, dengan sifat penelitian analitik-komparatif dengan pendekatan yuridis-normatif. Dari hasil penelitian di simpulkan bahwa dalam hukum positif para pelaku kejahatan main hakim sendiri dapat dijerat dengan pasal 170 KUHP, mengatur tentang sanksi hukum bagi para pelaku kekerasan terhadap orang atau barang di muka umum sedangkan dalam fiqh jinayah tersebut dikenal dengan istilah al-tawfuq dimana beberapa orang yang melakukan suatu kejahatan secara bersama tanpa kesepakatan sebelumnya karena adanya pengaruh psikologis dan pemikiran yang datang secara tiba-tiba dan uqubat yang diberikan pun akan berbeda di jatuhkan sesuai dengan peran masing-masing dari mereka.
\end{abstract}


Kata kunci: kejahatan, main hakim sendiri, hukum positif, fiqh jinayah

\section{A. Pendahuluan}

Dalam suatu perbuatan bisa dikatakan pidana jika ada peraturan yang melarang dan terdapat sanksi atau dapat diancamnya perbuatan tersebut dengan suatu ancaman pidana. Apakah orang yang melakukan perbuatan kemudian dijatuhi pidana, tergantung kepada apakah dalam perbuatan itu orang tersebut memiliki kesalahan. ${ }^{1}$ Seseorang tidak bisa dimintai pertanggungjawaban pidana tanpa terlebih dahulu dia melakukan perbuatan pidana tersebut. Adalah dirasa tidak adil jika tiba-tiba seseorang harus bertanggung jawab atas suatu tindakan, sedangkan dia sendiri tidak melakukan tindakan tersebut. ${ }^{2}$

Selanjutnya dipidana seorang tidaklah cukup apabila orang itu telah melakukan perbuatan yang bertentangan dengan hukum atau bersifat melawan hukum. Jadi meskipun perbuatan tersebut memenuhi rumusan delik dalam perundang-undangan dan tidak dibenarkan, namun hal tersebut belum memenuhi syarat dalam penjatuhan pidana. Untuk pemidanaan masih perlu adanya syaratsyarat dalam penjatuhan pidana yaitu jika seorang tersebut telah bersalah atau memiliki kesalahan. Orang tersebut harus diminta pertanggungjawaban atas perbuatannya atau jika dilihat dari sudut perbuatannya, perbuatannya baru dapat dipertanggungjawabkan kepada orang tersebut. ${ }^{3}$

Kesalahan merupakan suatu hal yang sangat penting untuk menjatuhi sanksi pidana pada seseorang. Tanpa itu, pertanggungjawaban pidana tidak akan pernah ada. Makanya tidak heran jika dalam hukum pidana dikenal asas "tiada pidana tanpa kesalahan" (geen straf zonder schuld). Asas kesalahan ini merupakan asas yang fundamental dalam hukum pidana, demikian fundamentalnya asas tersebut,

${ }^{1}$ Moeljatno, Asas-Asas Hukum Pidana, (Jakarta: Rineka Cipta, 2008), hlm. 165.

${ }^{2}$ Roeslan Saleh, Perbuatan Pidana dan Pertanggungjawaban Pidana, (Jakarta: Rineka Cipta, 1983), hlm. 20-23

${ }^{3}$ Sudarto, Hukum Pidana I, (Semarang: FH UNDIP, 1988), hlm. 85. 
sehingga meresap dan menggema dalam hampir semua ajaran penting dalam hukum pidana. ${ }^{4}$

Asas praduga tak bersalah (presumption of innocence) memiliki arti bahwa seseorang yang dituduh melakukan suatu kejahatan harus dianggap tidak bersalah sebelum hakim dengan bukti-bukti yang meyakinkan dan tidak ada unsur keraguan sedikitpun menyatakan dengan tegas kesalahannya itu. ${ }^{5}$ Ini sejalan dengan kaidah ushul fiqh yaitu الأصل براءة الذمة (hukum asal itu bebasnya seseorang dari tanggungan/berbagai tuntutan hukum). ${ }^{6}$ Dalam hal ini, tampak asas praduga tak bersalah lebih dekat dengan aturan dalam Islam bahwa seseorang tidak dibenarkan meneliti kesalahan orang lain kecuali memang dia ditugaskan untuk melakukannya, seperti polisi, jaksa, atau hakim yang bertugas menegakkan keadilan. $^{7}$

Hukuman hanya dapat diberlakukan bagi orang yang telah terbukti secara sah bersalah dengan keputusan yang telah ditetapkan oleh hakim yang mengikat (asas presumption of innocent) sebagai pelaku kejahatan (offender). Sebelum proses pembuktian memberikan kejelasan status orang yang dituduh melakukan pelanggaran, maka tetap berlaku prinsip praduga tak bersalah. Hal ini juga tetap berlaku pada pelaku yang telah terbukti tertangkap tangan melakukan suatu tindak pidana. $^{8}$

Dalam Al-Qur'an disebutkan larangan seseorang berlaku dzalim kepada sesama manusia yaitu QS. asy-Syura (42) ayat 39-43:

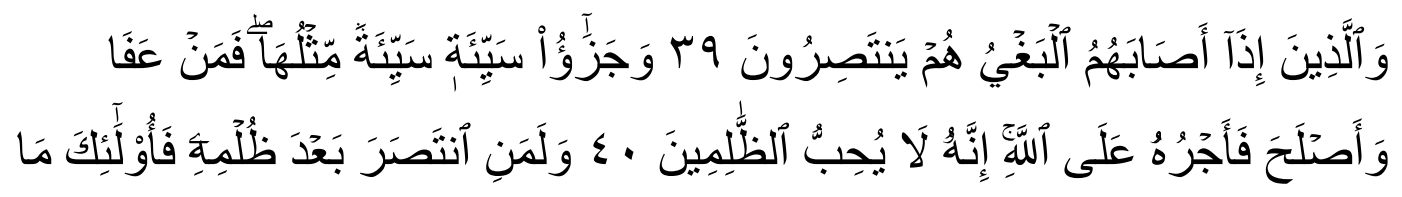

${ }^{4}$ Mahrus Ali, Dasar-Dasar Hukum Pidana, (Jakarta: Sinar Grafika, 2015), hlm. 157.

${ }^{5}$ Bambang Poernomo, Orientasi Hukum Acara Pidana Indonesia, (Bandung: Citra Aditya Bakti, 2000), hlm. 75.

${ }^{6}$ Abdul Kari Zaidan, Al-Wajiz fil-Qawaid Al-Fiqhiyah, (Muassasah Ar-Risalah, Cairo,tt). hlm. 37.

${ }^{7}$ M. Nurul Irfan, Hukum Pidana Islam, (Jakarta: Amzah, 2016), hlm. 18.

${ }^{8}$ Topo Santoso, Membumikan Hukum Pidana Islam, (Jakarta: Gema Insani, 2003), hlm. 11-14.

Sumardi Efendi 55 


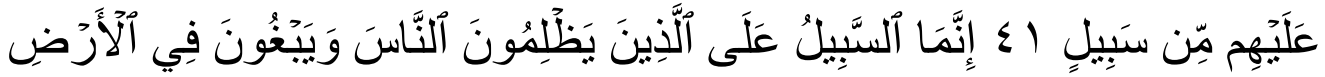

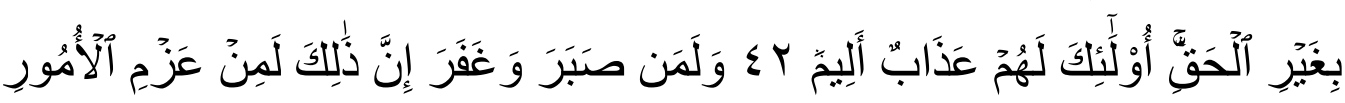

"Dan (bagi) orang-orang yang apabila mereka diperlakukan dengan zalim mereka membela diri. Dan balasan suatu kejahatan adalah kejahatan yang serupa, maka barang siapa memaafkan dan berbuat baik maka pahalanya atas (tanggungan) Allah. Sesungguhnya Dia tidak menyukai orang-orang yang zalim. Dan sesungguhnya orang-orang yang membela diri sesudah teraniaya, tidak ada satu dosapun terhadap mereka. Sesungguhnya dosa itu atas orang-orang yang berbuat zalim kepada manusia dan melampaui batas di muka bumi tanpa hak. Mereka itu mendapat azab yang pedih. Tetapi orang yang bersabar dan memaafkan, sesungguhnya (perbuatan) yang demikian itu termasuk hal-hal yang diutamakan".

Pada kenyataannya pemberlakuan hukum tak selamanya berjalan sebagaimana yang diharapkan. Hal ini terjadi karena kurangnya tingkat kepercayaan masyarakat kepada aparat penegak hukum (asas equal justice under law). ${ }^{9}$ Masyarakat beranggapan bahwa bila pelaku kejahatan (offender) diserahkan kepada aparat penegak hukum maka besar kemungkinan pelaku tersebut akan kembali mengulangi perbuatannya dikemudian hari. Oleh karena itu, harus ada strategi raksasa dalam upaya penanggulangan tindakan tersebut. Dalam hal ini, strategi raksasa adalah pengembalian kepercayaan masyarakat terhadap pemerintah dan penegakan hukum. ${ }^{10}$

Tindakan main hakim sendiri (eigenrichting) merupakan sesuatu persoalan yang tidak hanya terjadi sekali saja, namun sering, terutama di Indonesia. Tidakan ini merupakan suatu kejahatan, dimana tindakan main hakim sendiri (eigenrichting) kekerasan, khususnya kejadian atau peristiwa "penghakiman jalanan” oleh warga masyarakat yang kehidupannya terusik oleh seorang atau

${ }^{9}$ Ridwan, Membangun Integritas Penegak Hukum Bagi Terciptanya Penegakan Hukum Pidana Yang Berwibawa, (Jurnal Media Hukum, Vol 19, No 1, Tahun 2012), hlm. 89. url: http://journal.umy.ac.id/index.php/jmh/article/view/1979

${ }^{10}$ Zainuddin Ali, Sosiologi Hukum, (Jakarta: Sinar Grafika, 2008). 
sekelompok orang sebagai pelaku kejahatan (offender). ${ }^{11}$ Hanya saja sanksi yang dilakukan oleh perorangan atau kelompok sulit diukur berat ringannya, karena massa terkadang dapat bertindak sesuka hati dan tidak terkendali.

\section{B. Tindakan Eigenrichting Menurut Hukum Positif dan Fiqh jinayah}

Dalam Kamus Besar Bahasa Indonesia hakim adalah orang yang mengadili perkara, dan main hakim sendiri adalah perbuatan sewenang-wenang terhadap orang yang dianggap bersalah. ${ }^{12}$ Adapun tindak pidana main hakim sendiri merupakan terjemahan dari istilah Belanda yaitu "Eigenrichting" yang mempunyai arti tindakan main hakim sendiri, kekerasan yang dilakukan oleh masyarakat kepada pelaku tindak pidana sebagai hukuman tanpa melalui proses hukum yang berlaku. Perbuatan main hakim sendiri (eigenrichting) berkaitan dengan pelanggaran hak-hak orang lain dan tidak diperbolehkan perbuatan ini karena mengindikasikan rendahnya kesadaran masyarakat terhadap hukum. ${ }^{13}$

Menurut Sudikno Mertokusumo main hakim sendiri (eigenrichting) adalah tindakan untuk melaksanakan hak menurut kehendaknya sendiri yang bersifat sewenang-wenang, tanpa persetujuan dari pihak lain yang berkepentingan, pelaksanaan sanksi oleh perorangan/kelompok sehingga akan menimbulkan kerugian. Hanya saja sanksi yang dilakukan oleh perorangan atau kelompok sulit diukur berat ringannya, karena massa terkadang dapat bertindak sesuka hati dan tidak terkendali. ${ }^{14}$

Dari penjelasan diatas dapat disimpulkan bahwa kejahatan main hakim sendiri (eigenrichting) adalah tindakan/perbuatan yang dilakukan seseorang atau sekelompok orang secara sewenang-wenang dengan cara melakukan kekerasan

\footnotetext{
${ }^{11}$ Kiki Kristanto, Perbuatan Eigen Righting (Main Hakim Sendiri) dalam Perspektif Hukum Pidana, (Morality: Jurnal Ilmu Hukum, Vol. 2, No. 2 Tahun 2015), hlm. 1. url: https://jurnal.upgriplk.ac.id/index.php/morality/article/view/32

${ }^{12}$ Pusat Pembinaan dan Pengembangan Bahasa Depdikbud, Kamus Besar Bahasa Indonesia, (Jakarta: Balai Pustaka, 1995), hlm. 99.

${ }^{13}$ Andi Hamzah, Kamus Hukum, (Jakarta: Ghalia Indonesia, 1986), hlm. 167.

${ }^{14}$ Sudikno Mertokusumo, Hukum Acara Perdata Indonesia, (Yogyakarta: Liberty, 2010), hlm. 3.
} 
terhadap orang yang dianggap bersalah sebagai perbuatan untuk mengatasi permasaalahan yang dihadapi. Dengan kata lain merupakan sebagai perwujudan ledakan kemarahan (a hostile outbrust) atau ledakan tumpukan kekecewaan ( $a$ hostile frustration) terhadap hukum. ${ }^{15}$ Sehingga rasa kesal dan jenuh dari masyarakat pada umumnya dan para pencari keadilan khsusunya terhadap praktek criminal injustice system akibat kelemahan-kelemahan di atas, tidak akan menyelesaikan konflik tetapi justru memicu terbentuknya konflik lain (conflik creation) yang lebih besar. ${ }^{16}$

Dalam fiqh jinayah istilah tindak pidana biasa disebut dengan kata jarimah. Kata lain yang digunakan untuk tindak pidana istilah jarimah adalah jinayah. Hanya di kalangan fuqaha istilah jarimah pada umumnya digunakan untuk semua pelanggaran terhadap perbuatan-perbuatan yang dilarang oleh syara' baik mengenai jiwa ataupun lainnya. Sedangkan jinayah pada umumnya digunakan untuk menyebutkan perbuatan pelanggaran mengenai jiwa atau anggota badan, seperti pembunuhan dan melukai anggota badan tertentu. ${ }^{17}$

Defenisi jinayah menurut al-Jurjani mendefinisikan jinayah sebagai berikut:

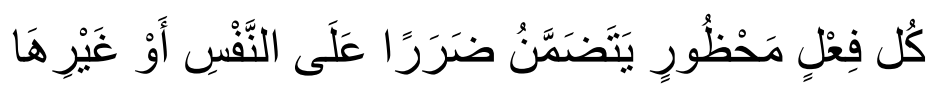

"Semua perbuatan yang dilarang yang mengandung mudharat terhadap nyawa atau selain nyawa".

Jinayah menurut Abdul Qadir Audah adalah sebagai berikut:

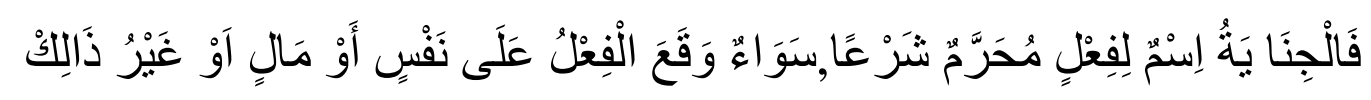

“Jinayah adalah suatu istilah untuk perbuatan yang dilarang oleh syara', baik perbuatan tersebut mengenai jiwa, harta, atau lainnya".

${ }^{15}$ Fuadi Isnawan, Pandangan Yuridis Sosiologis Fenomena Street Justice di dalam Kehidupan Bermasyarakat, (Jurnal Hukum Novelty, Vol. 9 No. 1, Tahun 2018), hlm. 20. url: http://journal.uad.ac.id/index.php/Novelty/article/view/8032

${ }^{16}$ Rizanizarli, Kriminalisasi Diluar KUHP dan Implikasinya terhadap Hukum Acara Pidana, (Kanun Jurnal Ilmu Hukum, Vol. 16, No 2 Tahun 2014), hlm. 282. http://jurnal.unsyiah.ac.id/kanun/article/view/6031/4969

${ }^{17}$ Imaning Yusuf, Fiqh Jinayah Hukum Pidana Islam, (Palembang: Rafah Press, 2009), hlm. 26. 
Adapun defenisi jarimah menurut Imam Al Mawardi sebagai berikut:

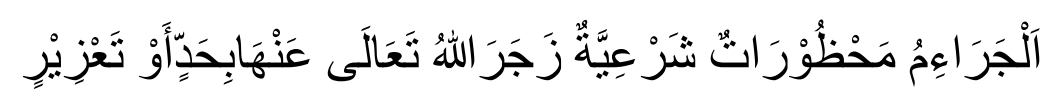

"Jarimah adalah perbuatan-perbuatan yang di larang oleh syara', yang di ancam oleh Allah dengan hukuman had atau ta 'zir".

Maka dari pengertian di atas dapat disimpulkan bahwa sebuah tindakan atau perbuatan seseorang yang mengancam keselamatan fisik manusia serta berpotensi menimbulkan kerugian pada harga diri atau harga kekayaan maka perbuatan tersebut diharamkan untuk dilakukan, bahkan pelakunya harus diberi hukuman sebagai sanksi yang mengikat yang harus ditegakan di dunia, bukan sekedar ancaman di akhirat.

Dalam fiqh jinayah setiap tindak pidana memiliki unsur-unsur tertentu apabila seseorang telah memenuhi syarat yang dimaksud dalam perbuatan (tindak) pidana, maka seseorang tersebut telah dianggap melakukan tindak pidana dan wajib mendapatkan perlakuan hukum sesuai dengan jenis tindak pidana yang dilakukannya. ${ }^{18}$

Dilihat dari unsur-unsur tindak pidana terbagi atas tiga yaitu unsur formil (al-rukn al-syar'i), unsur materiil (al-rukn al-madi), dan unsur moril (al-rukn aladabi).

1. Unsur formil (al-rukn al-syar'i) adalah unsur yang menyatakan bahwa seseorang dapat dinyatakan sebagai pelaku tindak pidana jika ada undangundang yang secara tegas melarang dan menjatuhkan sanksi kepada pelaku tindak pidana.

2. Unsur materiil (al-rukn al-madi) adalah unsur yang menyatakan bahwa seseorang dapat dijatuhkan pidana jika ia benar-benar terbukti melakukan suatu tindak pidana.

${ }^{18}$ Sudarsono, Pokok-Pokok Hukum Islam, (Jakarta: Sinar Grafika, 2011), hlm. 
3. Unsur moril (al-rukn al-adabi) adalah unsur yang menyatakan bahwa seseorang dapat dipersalahkan jika ia bukan orang gila, anak di bawah umur, atau sedang berada di bawah ancaman. ${ }^{19}$

\section{Sebab Terjadinya Kejahatan Main Hakim Sendiri (Eigenrichting)}

Pada hakikatnya tindakan menghakimi sendiri ini merupakan pelaksanaan sanksi/ kelompok. Hanya saja sanksi yang dilakukan oleh perorangan maupun kelompok sulit diukur berat ringannya, karena massa terkadang dapat bertindak kalap dan tidak terkendali. ${ }^{20}$ Begitu juga jika kita mencari tau apa sebab atau motifnya karena kejahatan merupakan suatu fenomena yang kompleks yang dapat dipahami dari berbagai sisi yang berbeda. Itu sebabnya dalam keseharian kita dapat menangkap berbagai komentar tentang suatu peristiwa kejahatan yang berbeda satu dengan yang lain. ${ }^{21}$

Adapun latar belakang timbulnya kejahatan merupakan sebab-sebab yang mendorong seseorang melakukan kejahatan. Latar belakang ini meliputi dua hal, yaitu: ${ }^{22}$

1. Latar belakang negatif, yaitu kejahatan yang dilakukan dengan sadar/niat artinya bahwa perbuatan yang dilakukan tersebut benar-benar dilakukan dengan sadar serta si pelaku benar-benar mengetahui akibatnya yaitu merugikan masyarakat, melanggar hukum sehingga perbuatannya dapat dinyatakan sebagai perbuatan jahat yang memenuhi unsur-unsur yang ditentang oleh masyarakat dan negara.

${ }^{19}$ Muhammad Abu Zahrah, al-Jarimah wa al-Uqubah fi Fiqh al-Islami, (Kairo: Dar al-Fikri al-Arabi, 1998), hlm. 111.

${ }^{20}$ Sudikno Mertokusumo, Mengenal Hukum Suatu Pengantar, (Yogyakarta: Liberty, 2003), hlm. 23.

${ }^{21}$ Topo Santoso dan Eva Achjani Zulfa, Kriminologi, (Jakarta: Rajawali Pers, 2013), hlm. 1.

${ }^{22}$ Lukman Hakim, Budaya Main Hakim Sendiri (Eigenrechting) Terhadap Pelaku Kejahatan Yang Tertangkap, (Jurnal Ar-Risalah: Media Keislaman, Pendidikan dan Hukum Islam, Vol. 14, No. 2, Tahun 2016), hlm. 88. url: http://ejournal.iaiibrahimy.ac.id/index.php/arrisalah/article/view/128 
2. Latar belakang positif, yaitu kejahatan yang dilakukan secara tidak sadar/tanpa niat, artinya bahwa si pelaku tidak mengetahui dengan pasti bahwa perbuatannya itu melanggar hukum, dapat dijatuhi hukuman dan tidak tahu akibat apa yang ditimbulkannya. Biasanya hal ini berkaitan dengan motif yang bertendensi pada kesulitan hidup sehari-hari atau karena terpaksa. Walaupun demikian perbuatan itu tetap dijatuhi hukuman oleh negara.

Selanjutnya dilihat dari faktor-faktor psikologis sosial yang dialami oleh para pelaku tindakan main hakim sendiri dapat di jelaskan sesuai framework tindakan main hakim sendiri yaitu sebagai berikut: ${ }^{23}$

1. Perceived Norm Violation, Para pelaku pada umumnya memiliki persepsi yang sangat negatif terhadap penjahat dan kejahatan, yang membuat para pelaku merasa marah, jengkel, kesal, dendam, kalap dan gemas. Perasaan tersebut menyebabkan mereka memiliki niat untuk "menghakimi” para penjahat.

2. Perceived Law Enforcementi, Para pelaku memiliki persepsi yang sangat negatif terhadap penegakan hukum. Hukum dinilai berjalan sangat buruk, tidak efektif, tidak efisien, dan tidak adil. Dalam konteks ini, polisi dipersepsi sebagai aparat yang tidak serius dalam menangani kejahatan dan juga menangani kasus-kasus penghakiman massa.

3. Relative Deprivation, Adanya deprivasi relatif yang dialami para pelaku penghakiman massa terutama tampak dari perasaan kecewa dan tidak puas yang disertai oleh emosi marah yang mereka alami akibat adanya kesenjangan antara harapan untuk dapat hidup secara aman.

4. Perceived Social Support, Para pelaku pada umumnya memiliki persepsi bahwa para penonton dan masyarakat setempat memberi dukungan terhadap kasus-kasus penghakiman massa.

5. Sosial learning, Para pelaku belajar dari kasus-kasus lain mengenai bentukbentuk atau jenis-jenis kekerasan. Mereka juga belajar (terutama melalui pengamatan langsung dan informasi yang di dengar/dibaca).

${ }^{23}$ Zainal Abidin, Penghakiman Massa Kajian Atas Kasus dan Pelaku, (Jakarta: Accompali Publishing, 2005), hlm. 189. 
6. Mob identification, Faktor-faktor tersebut tidak akan mungkin terwujud dalam bentuk penghakiman massa, jika para pelakunya tidak berada dalam massa dan mengidentifikasikan diri dalam masa.

7. Triggering, Pemicu merupakan faktor yang sangat penting dalam memperantai antecedent factors dengan faktor mob identification. Ia ibarat pemantik yang siap membakar emosi negatif orang-orang yang secara potensial sudah sangat marah dan memiliki niat untuk "menghakimi."

8. Perceived Social Role, Keterlibatan atau identifikasi seorang individu ke dalam massa dan menjadi salah seorang pelaku dalam penghakiman massa, ditentukan oleh bagaimana persepsi orang itu terhadap peran sosialnya dalam masyarakat.

Oleh karena itu dapat disimpulkan ada beberapa faktor yang dapat menyebabkan tindakan main hakim sendiri (eigenrichting) adalah sebagai berikut:

1. Faktor emosional pelaku tindakan main hakim sendiri (eigenrichting) yang sulit dikendalikan.

2. Ikut-ikutan atau dorongan orang lain yang pada saat itu melakukan tindakan main hakim sendiri (eigenrichting).

3. Rendahnya kesadaran terhadap hukum.

4. Menganggap tindakan menghakimi pelaku kejahatan (offender) adalah sesuatu yang biasa terjadi di masyarakat.

Namun jika kita telisik lebih dalam lagi penyebab utama seseorang melakukan kejahatan adalah kurangnya iman individu terhadap Allah Tuhan Yang Maha Hakim (iman determinisme), manakala iman menurun maka individu "siapapun dia" memiliki kecenderungan melakukan kejahatan, sebaliknya semakin tinggi iman maka individu lebih menjauhi tindak kejahatan. ${ }^{24}$

\section{Pertanggungjawaban Pidana Eigenrichting}

${ }^{24}$ Chairil A. Adjis dan Dudi Akasyah, Kriminologi Syariah: Kritik Terhadap Sistem rehabilitasi, (Jakarta: ICRI, 2004), hlm. 12. 
Perbuatan pidana menurut sistem KUHP dibagi atas kejahatan dan pelanggaran. Pelanggaran yang dimaksud yaitu perbuatan-perbuatan yang sifat melawan hukumnya baru dapat diketahui setelah ada peraturan yang menentukan. ${ }^{25}$ Perbuatan pidana tidak termasuk pengertian pertanggungjawaban pidana. Perbuatan pidana hanya merujuk kepada dilarang dan diancamnya perbuatan dengan suatu ancaman pidana. Apakah orang yang melakukan perbuatan kemudian dijatuhi pidana, tergantung kepada apakah dalam melakukan perbuatan itu orang tersebut memiliki kesalahan. ${ }^{26}$ Pertanggungjawaban pidana pada hakikatnya merupakan suatu mekanisme yang dibangun oleh hukum pidana untuk bereaksi terhadap pelanggaran atas "kesepakatan menolak" suatu perbuatan tertentu/kejahatan. ${ }^{27}$

Adapun hukum dibuat guna sebagai sarana kontrol sosial dalam kehidupan masyarakat, empat fungsi dasar hukum sebagai sarana kontrol sosial dalam kehidupan bermasyarakat, yaitu:

1. Untuk menetapkan hubungan-hubungan antar anggota masyarakat, dengan menunjukan jenis-jenis perilaku yang ada dalam masyarakat;

2. Menentukan pembagian kekuasaan;

3. Menyelesaikan sikap sengketa; dan

4. Memlihara fungsi-fungsi hubungan antar masyarakat. ${ }^{28}$

Dalam fiqh jinayah, pertanggungjawaban hanya dibebankan kepada orang yang masih hidup serta orang tersebut sudah mukallaf, ${ }^{29}$ artinya sebagai

\footnotetext{
${ }^{25}$ Moeljatno, Asas-Asas Hukum Pidana..., hlm. 71.

${ }^{26}$ Roeslan Saleh, Perbuatan Pidana dan Pertanggungjawaban..., hlm. 165.

${ }^{27}$ Chairul Huda, Dari Tiada Pidana Tanpa Kesalahan Menuju Kepada Tiada
} Pertanggungjawaban Pidana Tidana Tanpa Keslahan, (Jakarta: Kencana, 2006), hlm. 155.

${ }^{28}$ Fitriati, Perbuatan Main Hakim Sendiri dalam Kajian Kriminologis dan Sosiologis, (Jurnal Masalah-Masalah Hukum Jilid 41, Nomor 2, Tahun 2012), hlm. 164. url: https://ejournal.undip.ac.id/index.php/mmh/article/view/5744/9833

${ }^{29}$ Mukallaf adalah sebutan bagi orang yang perbuatannya terkait dengan khitab syar'i, mukallaf dianggap telah dapat dibebani hukum dan bertanggung jawab atas perbuatannya, perbuatan mukhalaf memiliki nilai dan resiko, sesuai dengan bentuk pekerjaannya, apakah ia mengerjakan perintah Allah SWT sehingga diberi pahala dan tanggungannya lepas, atau melakukan suatu larangan sehingga mendapat resiko 
pembebanan seseorang dengan hasil (akibat) perbuatan (atau tidak ada perbuatan) yang dikerjakannya dengan kemauan sendiri, dimana ia mengetahui maksud dan akibat dari perbuatannya itu. ${ }^{30}$ Pembebanan tersebut dikarenakan perbuatan yang dilakukan itu telah menimbulkan sesuatu yang bertentangan dengan hukum, artinya adanya perbutan melawan hukum ada yang disengaja dan ada yang karena kekeliruan yang dilarang secara syar'i baik dilarang melakukan atau dilarang meninggalkan. ${ }^{31}$ Pembebanan juga dikarenakan perbuatan itu sendiri dikerjakan berdasarkan keinginan dan kehendak yang timbul dalam dirinya bukan dorongan yang ditimbulkan oleh orang lain secara paksa (dipaksakan).

Para fuqaha menggunakan dua kaidah umum yang dapat keadaan bersalah. Dengan menerapkan keduanya, kita dapat mengetahui apakah seseorang bersalah atau tidak. Adapun kaidah tersebut yaitu:

1. Apabila pelaku melakukan perbuatan yang mubah (tidak dilarang) atau menyangka bahwa perbuatan itu dibolehkan, kemudian perbuatan itu menimbulkan keadaan yang tidak dibolehkan, maka ia bertanggungjawab secara pidana, baik keadaan tersebut ditimbulkannya dengan langsung maupun tidak langsung. Bila ternyata pelaku sebenarnya dapat menghindarinya. Apabila ia benar-benar tidak mampu menghindarinya, maka ia tidak ada pertanggungjawaban pidana terhadapnya.

2. Apabila perbuatan tidak diperbolehkan (dilarang), namun pelaku melakukannya, baik secara langsung maupun tidak langsung tanpa ada keadaan darurat dan apa yang ditimbulkan darinya menyebabkan pelaku harus bertanggungjawab secara pidana, baik perbuatan itu dapat dihindari ataupun tidak. $^{32}$

dosa dan tanggungannya belum lepas. Lihat Abdul Aziz Dahlan, Ensiklopedi Hukum Islam, Jilid. 4, (Jakarta: Ichtar Baru van Hoeve, 2003), hlm. 1219.

${ }^{30}$ Ahmad Wardi Muslich, Pengantar dan Asas Hukum Pidana Islam Fikih Jinayah (Jakarta: Sinar Grafika, 2004), hlm. 74.

${ }^{31}$ Hamzah Hasan, Hukum Pidana Islam 1 (Makassar: Alauddin University Press, 2014), hlm. 174.

${ }^{32}$ Alie Yafie, dkk, Ensiklopedia Hukum Pidana Islam, (Bogor: PT Kharisma Ilmu), hlm. 106. 
Jelas bahwa seseorang bertanggungjawab atas sesuatu perbuatan pidana yang secara sah dan telah diatur oleh nas (syar'i). Bisa dikatakan bahwa pidana itu dapat dikenakan secara berarti untuk tindakan ini telah ada aturannya dalam sistem hukum tertentu dan sistem hukum itu telah berlaku dan mengikat atas perbuatan itu. Singkatnya dapat dikatakan bahwa tindakan ini dibenarkan oleh sistem hukum. Hal inilah yang menjadi konsep mengenai pertanggungjawaban pidana.

Selanjutnya Allah SWT berfirman dalam Quran surat Al-An'am ayat 164:

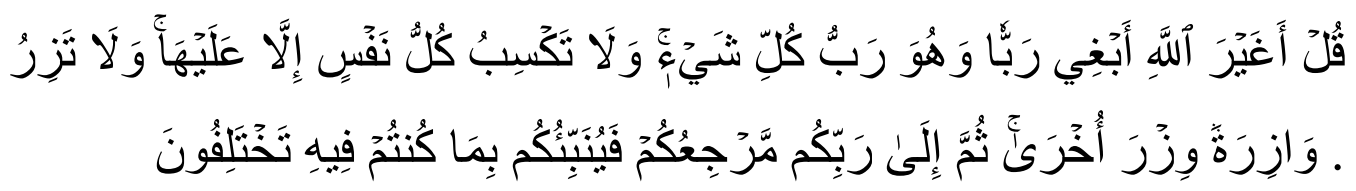

"Katakanlah: "Apakah aku akan mencari Tuhan selain Allah, padahal Dia adalah Tuhan bagi segala sesuatu. Dan tidaklah seorang membuat dosa melainkan kemudharatannya kembali kepada dirinya sendiri; dan seorang yang berdosa tidak akan memikul dosa orang lain. Kemudian kepada Tuhanmulah kamu kembali, dan akan diberitakan-Nya kepadamu apa yang kamu perselisihkan."

Berdasarkan ayat tersebut para fuqaha merumuskan sebuah kaidah yang berbunyi:

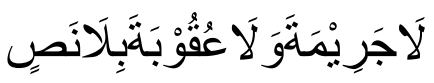

"Tidak ada jarimah (tindak kejahatan) dan tidak ada hukuman tanpa adanya aturan."

Dari kaidah tersebut, dapat dipahami bahwa perbuatan atau sikap tidak dipandangi sebagai jarimah, kecuali bila ada nas yang jelas melarang perbuatan tersebut. Apabila ada nas seperti itu, tidak ada tuntutan atau hukuman terhadap pelakunya. Jadi dari kedua kaidah tersebut, dapat disimpulkan bahwa tidak ada jarimah dan tidak ada hukuman, kecuali dengan suatu nas. Ini juga sesuai dengan yang di adopsi oleh hukum positif Kitab Undang-Undang Hukum Pidana (KUHP) Pasal 1 dinyatakan bahwa perbuatan yang pelakunya dapat dihukum adalah 
perbuatan yang sudah di sebutkan dalam perundang-undangan sebelum perbuatan itu di lakukan (nullum delictum nulla poena sine pravia legi poenali). ${ }^{33}$

Dalam fiqh jinayah, pertanggungjawaban didasarkan pada tiga prinsip, yaitu:

1. Melakukan perbuatan yang dilarang dan atau meninggalkan perbuatan yang diwajibkan.

2. Perbuatan tersebut dikerjakan atas kemauan sendiri. Artinya pelaku memiliki pilihan yang bebas untuk melaksanakan atau tidak melakukan perbuatan tersebut.

3. Pelaku mengetahui akan akibat perbuatan yang dilakukan. ${ }^{34}$

Selanjutnya dalam hukum positif, menurut Moeljatno pertanggungjawaban pidana juga harus memenuhi unsur-unsur tindak pidana:

1. Perbuatan (manusia)

2. Memenuhi rumusan dalam Undang-Undang (formil)

3. Bersifat melawan hukum (syarat materiil). ${ }^{35}$

Dengan adanya syarat tersebut terlihat bahwa para pelaku main hakim sendiri (eigenrichting) dapat dibebani pertanggungjawaban pidana atas tindakan yang telah dilakukan walaupun tindakan mereka bertujuan untuk pembelaan diri. Merujuk Pasal 170 KUHP mengatur tentang sanksi hukum bagi para pelaku kekerasan terhadap orang atau barang di muka umum. Kalau boleh dikatakan pasal ini adalah gabungan Pasal 351 KUHP tentang penganiayaan dan Pasal 55 KUHP tentang turut serta melakukan suatu perbuatan. Namun bila dibandingkan tentulah berbeda pengertian ataupun tujuan yang diinginkan oleh Pasal 170 KUHP dengan Pasal 351 dan 55 KUHP. Perlu ketelitian dalam penerapan pasal ini, karena bisa saja menyentuh ketentuan pasl 351. Maka daripada itu sering sekali hlm. 39.

${ }^{33}$ Andi Hamzah, Asas-asas Hukum Pidana, (Jakarta: Rineka Cipta, 2008),

${ }^{34}$ A. Djazuli, Fiqh Jinayah, Penanggulangan Kejahatan Dalam Islam, (Jakarta: Grafindo Persada, 2000), hlm. 242.

${ }^{35}$ Moeljatno, Perbuatan Pidana dan Pertanggungjawaban Dalam Hukum Pidana, (Yogyakarta: Bina Aksara, 1983), hlm. 60. 
para penyidik membuat pasal ini jounto 351 dan di tingkat penuntutan Penuntut Umum sering memakai jenis dakwaan Alternatif, dimana nantinya hakim dapat langsung memilih untuk menentukan dakwaan mana yang sekiranya cocok serta sesuai dengan hasil pembuktian di persidangan. ${ }^{36}$

Dalam fiqh jinayah perbuatan tersebut dikenal dengan istilah al-tawfuq dimana beberapa orang yang melakukan suatu kejahatan secara bersama tanpa kesepakatan sebelumnya karena adanya pengaruh psikologis dan pemikiran yang datang secara tiba-tiba. ${ }^{37}$ Adapun pemberian uqubat (sanksi) diberikan sesuai dengan tingkat perbuatan atau keikutsertaan pelaku dalam melakukan kejahatan main hakim sendiri (eigenrichting) tersebut apakah termasuk kategori hudud atau qishash. uqubat (sanksi) yang diberikan pun akan berbeda di jatuhkan sesuai dengan peran masing-masing dari mereka dimana dapat dikategorikan sebagai berikut:

1. Pembuat melakukan jarimah bersama-sama orang lain, artinya secara kebetulan bersama-sama.

2. Pembuat mengadakan persepakatan dengan orang lain untuk melaksanakan jarimah.

3. Menghasut (menyuruh) orang lain untuk membuat jarimah.

4. Memberi bantuan atau kesepakatan dengan berbagai cara, tanpa turut berbuat. ${ }^{38}$

Jadi pada prinsipnya pemberian uqubat demi keadilan dalam rangka menegakkan hukum yang dilakukan oleh semata-mata menjalankan keadilan Ilahi. Dilihat dari sejarahnya Rasulullah SAW. sebagai hakim pada saat itu hanya mengemban hukum Allah sehingga setiap keputusannya selalu berpegang kepada hukum Allah yaitu Al Qur'an. Uqubat yang tegas dan penegakannya sangat didukung dalam menciptakan masyarakat yang berkeadilan, selain itu uqubat berfungsi sebagai zawajir (pencegahan) karena dapat menjegah manusia dari

\footnotetext{
${ }^{36}$ Lilik Mulyadi, Hukum Acara Pidana, (Bandung: Citra Aditya Bakti, 2007), hlm. 87

${ }^{37}$ A. Djazuli, Fiqh Jinayah..., hlm. 17.

${ }^{38}$ Ahmad Hanafi, Asas-asas Hukum Pidana Islam, (Jakarta: Bulan Bintang, 1993), hlm. 136.
} 
kejahatan. ${ }^{39}$ Selanjutnya tujuan dari diminta pertanggungjawaban pidana bagi pelaku main hakim sendiri (eigenrichting) ini untuk mendapatkannya persamaan tujuan pemidanan dimata hukum ketika korban pada dasarnya adalah pelaku kejahatan, yaitu menyadarkan semua masyarakat untuk berbuat baik sehingga terpeliharanya ketentraman hidup dan kelangsungan hidup masyarakat.

\section{E. Kesimpulan}

Tindakan main hakim sendiri (eigenrichting) merupakan reaksi sosial/reaksi tidak resmi yang dilakukan oleh masyarakat saat menghadapi kejahatan yang tujuannya untuk membuat jera penjahat dan membuat penjahat lain takut melakukan kejahataan sehingga pada akhirnya akan dapat mengurangi kejahataan, namun tindakan tersebut tetap merupakan perbuatan pelanggaran hukum. Dalam hukum positif ini dapat jatuhi sanksi pidana sesuai perbuatan main hakim sendiri (eigenrichting), tindakan pelakunya "disengaja" artinya mereka yang melakukan tindakan tersebut mempunyai kemampuan untuk mengidentifikasi bahwa tindakan yang mereka lakukan adalah buruk dan dilarang oleh Undang-undang. Dalam fiqh jinayah perbuatan tersebut dikenal dengan istilah al-tawfuq dimana beberapa orang yang melakukan suatu kejahatan secara bersama tanpa kesepakatan sebelumnya karena adanya pengaruh psikologis dan pemikiran yang datang secara tiba-tiba dan uqubat (sanksi) yang diberikan pun akan berbeda di jatuhkan sesuai dengan peran masing-masing dari mereka.

\section{Daftar Pustaka}

Djazuli, A. 2000. Figh jinayah, Penanggulangan Kejahatan Dalam Islam. Jakarta: Grafindo Persada.

Dahlan, Abdul Aziz. 2003. Ensiklopedi Hukum Islam. Jakarta: Ichtar Baru van Hoeve.

\footnotetext{
${ }^{39}$ Abdurrahman al-Maliki dan Ahmad ad-Da'ur, Nidzam al-Uqubat dan Ahkam al-Bayyinat, (Bogor: Pustaka Thariqul Izzah, 2004), hlm. 3
} 
Zaidan, Abdul Kari. tt. Al-Wajiz fil-Qawaid Al-Fiqhiyah. Kairo: Muassasah ArRisalah.

Audah, Abdul Qadir. 1994. al-Tasyri' al-Jina'i al-Islami. Beirut: Muassasah alRisalah.

al-Maliki, Abdurrahman dan Ahmad ad-Da'ur. 2004. Nidzam al-Uqubat dan Ahkam al-Bayyinat. Bogor: Pustaka Thariqul Izzah.

Al-Mawardi, Abu Al-Hasan. 1975. Al-Ahkam As-Sulthaniyah. Mesir: Musthafa Al-Baby Al-Halaby.

Hanafi, Ahmad. 1993. Asas-asas Hukum Pidana Islam. Jakarta: Bulan Bintang.

Muslich, Ahmad Wardi. 2004. Pengantar dan Asas Hukum Pidana Islam Fikih Jinayah. Jakarta: Sinar Grafika.

al-Jurjani, Ali bin Muhammad. 1999. al-Ta'rifat. Beirut: Dar al-Kutub al-Arabi.

Sabiq, Al-Sayyid. 1980. Fiqh al-Sunnah. Beirut: Dar al-Fikri.

Hamzah, Andi. 2008. Asas-asas Hukum Pidana. Jakarta: Rineka Cipta. 1986. Kamus Hukum. Jakarta: Ghalia Indonesia.

Poernomo, Bambang. 2000. Orientasi Hukum Acara Pidana Indonesia. Bandung: Citra Aditya Bakti.

Adjis, Chairil A. dan Dudi Akasyah. 2004. Kriminologi Syariah: Kritik Terhadap Sistem Rehabilitasi. Jakarta: ICRI.

Huda, Chairul. 2006. Dari Tiada Pidana Tanpa Kesalahan Menuju Kepada Tiada Pertanggungjawaban Pidana Tidana Tanpa Keslahan. Jakarta: Kencana.

Fitriati. 2012. Perbuatan Main Hakim Sendiri dalam Kajian Kriminologis dan Sosiologis. Jurnal Masalah-Masalah Hukum. Jilid 41, Nomor 2.

Isnawan, Fuadi. 2018. Pandangan Yuridis Sosiologis Fenomena Street Justice di dalam Kehidupan Bermasyarakat. Jurnal Hukum Novelty. Vol. 9 No. 1.

Hasan, Hamzah. 2014. Hukum Pidana Islam 1. Makassar: Alauddin University Press. 
Yusuf, Imaning. 2009. Fiqh jinayah Hukum Pidana Islam. Palembang: Rafah Press.

Kristanto, Kiki. 2015. Perbuatan Eigen Righting (Main Hakim Sendiri) dalam Perspektif Hukum Pidana. Morality: Jurnal Ilmu Hukum. Vol. 2, No. 2.

Mulyadi, Lilik. 2007. Hukum Acara Pidana. Bandung: Citra Aditya Bakti.

Hakim, Lukman. 2016. Budaya Main Hakim Sendiri (Eigenrechting) Terhadap Pelaku Kejahatan Yang Tertangkap. Jurnal Ar-Risalah: Media Keislaman, Pendidikan dan Hukum Islam. Vol. 14, No. 2.

Irfan, M. Nurul. 2016. Hukum Pidana Islam. Jakarta: Amzah.

Ali, Mahrus. 2015. Dasar-Dasar Hukum Pidana. Jakarta: Sinar Grafika.

Moeljatno. 2008. Asas-Asas Hukum Pidana. Jakarta: Rineka Cipta,. 1983. Perbuatan Pidana dan Pertanggungjawaban Dalam Hukum

Pidana. Yogyakarta: Bina Aksara.

Abu Zahrah, Muhammad. 1998. al-Jarimah wa al-Uqubah fi Fiqh al-Islami. Kairo: Dar al-Fikri al-Arabi.

Pusat Pembinaan dan Pengembangan Bahasa Depdikbud. 1995. Kamus Besar Bahasa Indonesia. Jakarta: Balai Pustaka.

Ridwan. 2012. Membangun Integritas Penegak Hukum Bagi Terciptanya Penegakan Hukum Pidana Yang Berwibawa. Jurnal Media Hukum. Vol 19, No 1. Rizanizarli. 2014. Kriminalisasi Diluar KUHP dan Implikasinya terhadap Hukum Acara Pidana. Kanun Jurnal Ilmu Hukum. Vol 16, No 2.

Saleh, Roeslan. 1983. Perbuatan Pidana dan Pertanggungjawaban Pidana. Jakarta: Rineka Cipta.

Sudarsono. 2011. Pokok-Pokok Hukum Islam. Jakarta: Sinar Grafika.

Sudarto. 1988. Hukum Pidana I. Semarang: FH UNDIP.

Mertokusumo, Sudikno. 2010. Hukum Acara Perdata Indonesia. Yogyakarta: Liberty. 
Santoso, Topo dan Eva Achjani Zulfa. 2013. Kriminologi. Jakarta: Rajawali Pers.

al-Zuhaili, Wahbah. 1997. Al-Fiqh Al-Islami Wa Adillatuhu. Beirut: Dar al-Fikri.

Abidin, Zainal. 2005. Penghakiman Massa Kajian Atas Kasus dan Pelaku. Jakarta: Accompali Publishing.

Ali, Zainuddin. 2008. Sosiologi Hukum. Jakarta: Sinar Grafika. 